\title{
Comparison of Sustainability Factors Influencing Environmental, Economic and Social Sustainability- An Empirical Study in an Emerging Economy
}

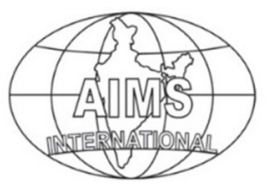

DOI: $10.26573 / 2018.12 .3 .2$

Volume 12, Number 3

September 2018, pp. 161-169

\author{
R. Nandagopal \\ XIME, Cochin \\ B. Uma Maheswari \\ D. Kavitha \\ PSG Institute of Management \\ (uma@psgim.ac.in) \\ (kavitha@psgim.ac.in)
}

\begin{abstract}
Sustainability symbolizes an equitable world with responsible governments, businesses and people striving to protect the natural environment and social equity, at the same time not compromising in their quest for economic growth (Adams \& Zutshi 2004). Though SMEs form the backbone of an economy, research on sustainability has focused only on large firms. This study, carried out among SMEs provides a fresh perspective on sustainability. The objective of the study is to examine the factors driving the three pillars of economic, environmental and social sustainability in the context of SMEs in India. Murphy (2012) defined environmental sustainability as "the practice of responding to environmental issues in a socially responsible manner". According to Beheiry et al. (2006), the economic pillar of sustainability is "the implementation of business practices with the assurance of future economic growth". Social sustainability signifies the responsibility of a business towards the social well-being of the stakeholders. The sustainability factors considered for this study was perceived benefits, firm competency and market forces. It is highly essential to understand the factors which strongly drive sustainability practices so that firms would be able to identify potential strategies that could be adopted to achieve their sustainability agenda. This study was undertaken among 220 SMEs operating in an industrial city in South India. An instrument was developed based on extensive review of literature and tested for reliability and validity. Appropriate statistical tools were applied and the data was analysed. The study found the strong driving forces with regard to the factors perceived benefits, firm competency and market forces. The results of this study also provide the basic framework for policy makers to identify the ways and means through which the sustainability quotient of the SMEs could be enhanced.
\end{abstract}

Keywords: Sustainability, Small and Medium Enterprises, Emerging Economy, Drivers of Sustainability

\section{Introduction}

Sustainability symbolizes an equitable world with responsible governments, businesses and people striving to protect the natural environment and social equity, at the same time not compromising in their quest for economic growth (Adams \& 
Zutshi 2004). World Commission on Environment and Development (WCED 1987) states that, "Sustainable Development is development that meets the needs of the present without compromising the ability of future generations to meet their own needs". Sustainability emphasises that mere economic returns are not sufficient for a business to thrive. Such economic returns could be the focus from a short term perspective, but in the long run all three dimensions of sustainability- Environmental, Economic and Social should be given equal prominence.

This empirical study based on the grounded theory approach is undertaken on small and medium enterprises in the Coimbatore district of Tamil Nadu, South India. A self-made economy, this city houses more than 25,000 small, medium and large industries and is a beehive of entrepreneurial activity. This pioneering research study focuses on the impact of various factors that drive the environmental, economic and social sustainability factors in small and medium enterprises among the members of CODISSIA, Coimbatore District Small Scale Industries Association which is one of the largest associations for SMEs in the country. The literature review brought forth certain factors which drive sustainability which includes perceived benefits, firm competence and the market forces which drive sustainability. This kind of empirical study is essential because of the dearth of research in the domain of sustainability, especially in the context of a developing economy like India

\section{Literature Review and Hypothesis Development}

Studies in the domain of sustainability have identified various factors which drive a firm towards sustainability. These factors have been classified as Driving Dependence, Push-Pull, Internal-External factors. The commonly identified factors are improved relationship with the government (Patten 1999), identifying new opportunities in business(Chen 2008), financial benefits (Williams \& Schaefer 2013), organizational change (Revell et al., 2010), pressure from stakeholders (Bai \& Sarkis, 2010), financial institutions (Collins et al,2010), top management commitment (Williams \& Schaefer 2013). The review also showed that these drivers have not been comprehensively explored from the small business perspective. The small and medium enterprises are the second largest employment generator in India after agriculture and it forms the backbone of the Indian economy and studies based on the factors driving the three pillars of sustainability have been very rare in a developing economy like India. It is highly essential to understand the factors which strongly drive environmental, economic and social sustainability practices so that firms would be able to identify the potential strategies that they can adopt to satisfy their sustainability agenda.

Literature states that the factors driving sustainability in firms is based on certain theories of the firm including the shareholder theory, stakeholder theory and the resource based view theory. The shareholder theory of the firm, states that the ultimate duty of any firm is to maximize returns for its shareholders. The shareholders provide the financial support or capital to run the business and therefore have considerable influence and authority to expect maximum returns from the same (Hill \& Jones 1992 and Madden et al. 2006). Firms would therefore undertake sustainability practices only if they perceive certain benefits resulting out of such activities which would in turn satisfy their shareholders. This theory forms the basis of the first proposition on the perceived benefits. 
According to the Resource Based View (RBV) theory, the tangible and intangible resources available with a firm will determine the nature of activities or the strategies which it would execute (Conner \& Prahalad 1996; Hart 1995; Russo \& Harrison 2005). Lozano et al. (2015) stated that the appropriate bundling of these resources helps acquire competitive advantage. This competitive advantage becomes a sustainable competitive advantage when it cannot be replicated by its competitors. The RBV theory ensures the maximum utilization of available resources. Lozano et al. (2015) also state that the theory contributes to the social dimension, as it affects the internal stakeholders. Hence the proposition based on the firm competence was formulated

Drawing from the stakeholder theory, Ansoff (1965) states that firms strive to balance the conflicting demands of the different stakeholders. In the context of corporate sustainability, Cormier et al. (2004) state that stakeholder theory offers the micro framework for firms to undertake sustainable development activities to satisfy the interest of the various stakeholders or the external market forces. Hence, the final proposition of this study on the market forces was arrived at. Murphy (2012) defined environmental sustainability as "The practice of responding to environmental issues in a socially responsible manner". According to Beheiry et al. (2006), the economic pillar of sustainability is "The implementation of business practices with the assurance of future economic growth". Social sustainability means the responsibility of business towards the social well-being of the stakeholders. Socially sustainable firms add value to the society in which they operate.

Based on the comprehensive literature review and conceptual framework the propositions arrived at is presented in Table 1 .

Table 1 Propositions and Corresponding Literature Review

\begin{tabular}{|c|c|}
\hline PROPOSITIONS & LITERATURE REVIEW \\
\hline $\begin{array}{l}\text { There is a positive relationship between } \\
\text { Perceived Benefits and Environmental, } \\
\text { Economic and Social Sustainability } \\
\text { Practices }\end{array}$ & $\begin{array}{l}\text { Hill \& Jones } 1992 \text { and Madden et al. 2006, } \\
\text { Stubblefield Loucks et al. 2010, Battacharya et al. } \\
\text { 2008, Marin \& Ruiz 2007, Aragon- Correa et al. } \\
\text { 2008, Baron et al. } 2014\end{array}$ \\
\hline $\begin{array}{l}\text { There is a positive relationship between } \\
\text { Firm Competence and Environmental, } \\
\text { Economic and Social Sustainability } \\
\text { Practices }\end{array}$ & $\begin{array}{l}\text { Conner \& Prahalad 1996; Hart 1995; Russo \& } \\
\text { Harrison } 2005 \text {, Brammer et al. 2012; Collins et al. } \\
\text { 2010, Williams \& Scheafer 2013, Castka et al. } \\
2004 \text {, Revell et al. } 2010\end{array}$ \\
\hline $\begin{array}{l}\text { There is a positive relationship between } \\
\text { Market Forces and Environmental, } \\
\text { Economic and Social Sustainability } \\
\text { Practices. }\end{array}$ & $\begin{array}{l}\text { Jones \& Wicks 1999; Kassinis \& Vafeas } 2002, \\
\text { Schaper 2002, Yu and Bell's 2007, Masurel 2007, } \\
\text { Ervin et al. 2013; Bonilla Priego et al. } 2011\end{array}$ \\
\hline
\end{tabular}

\section{Research Methodology}

This is an empirical study conducted in the Coimbatore district of Tamil Nadu. The sampling frame is derived from the members listed in CODISSIA which is the manufacturing cluster representing SMEs in Coimbatore city. Of the 1691 members, only 1102 members were found fit to the definition of SMEs and were operating with a labour strength of more than 10 employees. An interview request was sent to all the 1102 members through e-mails, mails and phone calls. 262 members out of the selected population responded from the data collection process. Out of this 262, 
42 questionnaires were found to be incomplete and therefore, could not be included for further analysis and finally the sample size of 220 was achieved which comprised of ancillary machinery manufacturers. This sample size approximates to $23 \%$ of the population considered. In this study statistical correlation was used to understand the degree or extent to which environmental, economic and social sustainability practices co-relate with the perceived benefits, firm competency and market forces.

The sampling technique used was simple random sampling and the data was collected using a structured interview schedule. The questionnaire comprised of questions relating to demographic characteristics, perceived benefits (PB), Firm Competence and Market Forces (MF) on the Environmental (ES), Economic (EC) and Social (SO) sustainability practices.

Table 2 Demographic Characteristics

\begin{tabular}{|l|c|c|}
\hline \multicolumn{1}{|c|}{ Demographic Characteristics } & Frequency & Percentage \\
\hline Number of people employed full time in the organization & & \\
\hline Up to 15 & 72 & 32.7 \\
\hline $15-30$ & 76 & 34.5 \\
\hline More than 30 & 72 & 32.7 \\
\hline Age of the business & & \\
\hline Less than 10 & 100 & 45.5 \\
\hline $10-20$ & 64 & 29.1 \\
\hline More than 20 & 56 & 25.5 \\
\hline The generation currently managing the business & & \\
\hline First & 104 & 47.3 \\
\hline Second & 96 & 43.6 \\
\hline Third & 20 & 9.1 \\
\hline
\end{tabular}

\section{Instrument Validity}

The instrument used for this study was tested for reliability and validity. The reliability of the instrument was tested using the Item Purification Process. The Cronbach alpha scores and the composite reliability scores ensured the construct validity and the internal consistency. These results are depicted in Table 3 and Table 4.

Table 3 Validity Scores

\begin{tabular}{|l|c|c|c|c|}
\hline Construct & $\begin{array}{c}\text { Cronbach } \\
\text { Alpha }\end{array}$ & $\begin{array}{c}\text { Composite } \\
\text { Reliability } \\
\text { (Environmental) }\end{array}$ & $\begin{array}{c}\text { Composite } \\
\text { Reliability } \\
\text { (Economic) }\end{array}$ & $\begin{array}{c}\text { Composite } \\
\text { Reliability } \\
\text { (Social) }\end{array}$ \\
\hline PB & 0.814866 & 0.860313 & 0.850237 & 0.860567 \\
\hline FC & 0.566663 & 0.755972 & 0.748787 & 0.756482 \\
\hline MF & 0.799562 & 0.846676 & 0.843412 & 0.845655 \\
\hline
\end{tabular}

Table 4 Cronbach Alpha and Composite Reliability of Environmental, Economic and Social Sustainability Practices

\begin{tabular}{|l|c|c|}
\hline Construct & Cronbach Alpha & Composite Reliability \\
\hline Envtl & 0.799291 & 0.851803 \\
\hline Eco & 0.896869 & 0.924344 \\
\hline Social & 0.764996 & 0.833422 \\
\hline
\end{tabular}




\section{Results and Discussion}

The objective of this study is to establish the positive relationship between perceived benefits (PB), Firm Competence and Market Forces (MF) on the Environmental (ES), Economic (EC) and Social (SO) sustainability practices. The results clearly indicate a positive correlation between these constructs as depicted in Table 6 .

While the results portray the prevailing drivers of sustainability, it also clearly brings out certain factors which predominantly drive environmental sustainability as compared to economic and social sustainability practices. The research shows that environmental sustainability initiatives were driven more by the perceived benefits relating to new opportunities $(\mathrm{r}=0.741)$, retaining qualified employees $(\mathrm{r}=$ $0.737)$ and cordial relationships with government $(r=0.572)$. Such new opportunities in terms of sustainable solutions seem to garner a lot of positive attention from many stakeholders and more importantly the customers and the government which in turn benefits the firms. Qualified employees like to be identified with green initiatives and retaining them becomes much easier.

Table 5 Correlation Matrix

\begin{tabular}{|c|c|c|c|c|}
\hline & & ES & EC & SO \\
\hline \multirow{2}{*}{ PB } & Pearson Correlation & $.930^{* *}$ & $.791^{* * *}$ & $.908^{* *}$ \\
\hline & Sig. (2-tailed) & .000 & .000 & .000 \\
\hline \multirow{2}{*}{$\mathrm{FC}$} & Pearson Correlation & $.838^{* *}$ & $.849^{* *}$ & $.828^{* * *}$ \\
\hline & Sig. (2-tailed) & .000 & .000 & .000 \\
\hline \multirow{2}{*}{ MF } & Pearson Correlation & $.925^{* *}$ & $.489^{* * *}$ & $.882^{* *}$ \\
\hline & Sig. (2-tailed) & .000 & .000 & .000 \\
\hline a. & List wise $\mathrm{N}=220$ & & & \\
\hline
\end{tabular}

On the other hand economic sustainability was driven by cost-savings $(r=0.882)$, profitability $(r=0.751)$ and first-mover advantage $(r=0.721)$. This is in line with the concept of the business case of sustainability. According to Salzmann et al. (2005), the economic justification for corporate sustainability is defined as "A strategic and profit-driven corporate response to environmental and social issues caused through the organization's primary and secondary activities." Social sustainability factors were driven by culture $(\mathrm{r}=0.694)$, employees $(\mathrm{r}=0.631)$ and new opportunities in business $(r=0.599)$. The study goes in agreement of the theory of Porter $\&$ Kramer (2006) who emphasize the social component of sustainability by stating that "Successful corporations need a healthy society, a healthy society creates expanding demand for business, as more human needs are met and aspirations grow."

The study clearly showed that the advantages perceived from the three pillars of sustainability have a distinctive focus. Of the different firm competencies, the study clearly showed that the values $(r=0.374)$ and the commitment from the top management drives $(\mathrm{r}=0.562)$ all three sustainability practices. While Associations/Networks ( $\mathrm{r}=0.737)$, Customers $(\mathrm{r}=0.687)$ and Social Expectation $(\mathrm{r}$ $=0.636)$ were the market forces that drive both Environmental and Social Sustainability Practices, completely different factors like Stakeholder Commitment (r $=0.882)$, Globalization $(\mathrm{r}=0.882)$ and Technology $(\mathrm{r}=0.751)$ drive Economic Sustainability Initiatives. Therefore, the research shows that distinctive focus on the 
different factors is essential to encourage SMEs towards environmental, economic and social sustainability practices.

Table 6 A Comparison of the Different Sustainability Factors Influencing Environmental, Economic and Social Sustainability Practices

\begin{tabular}{|l|l|l|l|}
\hline $\begin{array}{c}\text { Sustainability } \\
\text { factors }\end{array}$ & \multicolumn{1}{|c|}{ Environmental } & \multicolumn{1}{|c|}{ Economic } & \multicolumn{1}{c|}{ Social } \\
\hline $\begin{array}{l}\text { Perceived } \\
\text { Benefits }\end{array}$ & $\begin{array}{l}\text { Eco friendly production } \\
\text { Improvement in the } \\
\text { employability skills } \\
\text { through academic } \\
\text { networking Government } \\
\text { Lobby }\end{array}$ & $\begin{array}{l}\text { Non-conventional energy } \\
\text { systems Viz. Solar energy } \\
\text { People, Planet, Profits (3P) } \\
\text { Competitive edge }\end{array}$ & $\begin{array}{l}\text { New social standards } \\
\text { Congenial work place } \\
\text { Less carbon print } \\
\text { businesses } \\
\text { Organizational culture }\end{array}$ \\
\hline $\begin{array}{l}\text { Firm } \\
\text { competency }\end{array}$ & $\begin{array}{l}\text { Eco-Concern in a holistic } \\
\text { way Realization from } \\
\text { strategic level }\end{array}$ & $\begin{array}{l}\text { Social Cost- benefit balance } \\
\text { Better Resources utilization } \\
\text { and economy at all levels }\end{array}$ & $\begin{array}{l}\text { Improved social index } \\
\text { Fraternity at income } \\
\text { and technology } \\
\text { engagement }\end{array}$ \\
\hline Market Forces & $\begin{array}{l}\text { Matured industry } \\
\text { interaction Socially } \\
\text { responsible customers }\end{array}$ & $\begin{array}{l}\text { Responsibility at micro } \\
\text { level Green products for the } \\
\text { world }\end{array}$ & $\begin{array}{l}\text { Societal brands } \\
\text { Interaction among all } \\
\text { the partners of value } \\
\text { chain }\end{array}$ \\
\hline
\end{tabular}

This study adds to the existing literature on sustainability, especially in the context of small and medium firms. Considering the importance of SMEs to the country's economy, it is imperative to identify which strategies work and how they work in order to encourage their smooth transition towards sustainability. This study has thrown light on the factors which are strong drivers of sustainability. The results of this study also provide the basic framework for policy makers to identify the ways and means through which the sustainability quotient of the SMEs could be enhanced. Inputs from this study could be used to formulate training modules on sustainability issues and implementation of sustainability practices could be encouraged, especially in developing economies like India to achieve the aim of creating responsible SMEs of the future.

\section{References}

1. Adams, C \& Zutshi, A 2004, 'Corporate social responsibility: why business should act responsibly and be accountable', Australian accounting review, vol. 14, no. 34, pp. 31-39.

2. Ansoff Igor, H 1965, Corporate Strategy, McGraw-Hill, New York.

3. Aragón-Correa, JA, Hurtado-Torres, N, Sharma, S \& García-Morales, VJ 2008, 'Environmental strategy and performance in small firms: A resource-based perspective', Journal of Environmental Management, vol. 86, no. 1, pp. 88-103

4. Bai, C \& Sarkis, J 2010, 'Green supplier development: analytical evaluation using rough set theory', Journal of Cleaner Production, vol. 18, no. 12, pp. 12001210.

5. Baron, SL, Beard, S, Davis, LK, Delp, L, Forst, L, Kidd $\square$ Taylor, A \& Welch, LS 2014, 'Promoting integrated approaches to reducing health inequities among 
low $\square$ income workers: Applying a social ecological framework, 'American Journal of Industrial Medicine, vol. 57, no. 5, pp. 539-556.

6. Battacharya, CB, Sen, S \& Korschun, D 2008, 'Using corporate social responsibility to win the war for talent', MIT Sloan Management Review, vol. 49 no. 2, pp. 37-48.

7. Beheiry, SM, Chong, WK \& Haas, CT 2006, 'Examining the business impact of owner commitment to sustainability', Journal of Construction Engineering and Management, vol. 132, no.4, pp. 384-392.

8. Bonilla Priego, MJ, Najera, JJ \& Font, X 2011, 'Environmental management decision-making in certified hotels', Journal of Sustainable Tourism, vol. 19, no. 3, pp. 361-381.

9. Brammer, S, Hoejmose, S \& Marchant, K 2012, 'Environmental management in SMEs in the UK: practices, pressures and perceived benefits', Business Strategy and the Environment, vol. 21, no.7, pp. 423-434.

10. Castka, P, Balzarova MA \& Bamber, CJ 2004, 'How can SMEs effectively implement the CSR agenda? A UK case study perspective', Corporate Social Responsibility and Environment Management, vol. 11, no. 1, pp. 140-149.

11. Chen, YS 2008, 'The positive effect of green intellectual capital on competitive advantages of firms', Journal of Business Ethics, vol. 77, no. 3, pp. 271-286.

12. Collins, SL, Carpenter, SR, Swinton, SM, Orenstein, DE, Childers, DL, Gragson, TL \& Whitmer, AC 2010, 'An integrated conceptual framework for long-term social-ecological research', Frontiers in Ecology and the Environment, vol. 9, no. 6, pp. 351-357.

13. Conner, KR \& Prahalad, CK 1996, 'A resource-based theory of the firm: Knowledge versus opportunism', Organization Science, vol. 7, no. 5, pp. 477501.

14. Cormier, D, Gordon, IM \& Magnan, M 2004, 'Corporate environmental disclosure: contrasting management's perceptions with reality', Journal of Business Ethics, vol. 49, no. 2, pp. 143-165.

15. Ervin, D, Wu, J, Khanna, M, Jones, C \& Wirkkala, T 2013, 'Motivations and barriers to corporate environmental management', Business Strategy and the Environment, vol. 22, no. 6, pp. 390-409.

16. Hart, SL 1995, 'A natural-resource-based view of the firm', Academy of Management Review, vol. 20, no. 4, pp. 986-1014.

17. Hill, CW \& Jones, TM 1992, 'Stakeholder $\square$ agency theory', Journal of Management Studies, vol. 29, no. 2, pp. 131-154.

18. Jones, TM \& Wicks, AC 1999, 'Convergent stakeholder theory', Academy of Management Review, vol. 24, no. 2, pp. 206-221.

19. Kassinis, G \& Vafeas, N 2002, 'Corporate boards and outside stakeholders as determinants of environmental litigation', Strategic Management Journal, vol. 23, no. 5, pp. 399-415.

20. Lozano, R, Carpenter, A \& Huisingh, D 2015, 'A review of 'theories of the firm'and their contributions to Corporate Sustainability', Journal of Cleaner Production, vol. 106, pp. 430-442.

21. Madden, TJ, Fehle, F \& Fournier, S 2006, 'Brands matter: An empirical demonstration of the creation of shareholder value through branding', Journal of the Academy of Marketing Science, vol.34, no. 2, pp. 224-235. 
22. Marin, L \& Ruiz, S 2007, "I need you too!" Corporate identity attractiveness for consumers and the role of social responsibility', Journal of Business Ethics, vol. 71, no. 3, pp. 245-260

23. Masurel, E 2007, 'Why SMEs invest in environmental measures: sustainability evidence from small and medium $\square$ sized printing firms ?', Business Strategy and the Environment, vol.16, no. 3, pp. 190-201.

24. Murphy, K 2012, 'The social pillar of sustainable development: a literature review and framework for policy analysis', Sustainability: Science, Practice, \& Policy, vol. 8, no. 1, pp. 15-29.

25. Patten, DT 1991, 'Human Impacts in the Greater Yellowstone Ecosystem: Evaluating Sustainability Goals and Eco $\square$ redevelopment', Conservation Biology, vol. 5, no. 3, pp. 405-411.

26. Revell, A, Stokes, D \& Chen, H 2010, 'Small businesses and the environment: turning over a new leaf ?', Business Strategy and the Environment, vol. 19, no. 5, pp. 273-288.

27. Russo, MV \& Harrison, NS 2005, 'Organizational design and environmental performance: Clues from the electronics industry', Academy of Management Journal, vol. 48, no. 4, pp. 582-593.

28. Schaper, M 2002, 'Introduction: the essence of ecopreneurship', Greener Management International, no. 38, pp. 26-30.

29. Stubblefield Loucks, E, Martens, ML \& Cho, CH 2010, 'Engaging small-and medium-sized businesses in sustainability', Sustainability Accounting, Management and Policy Journal, vol.1, no.2, pp.178-200.

30. WCED, U 1987, Our common future. World Commission on Environment and Development, Oxford University Press.

31. Williams, S \& Schaefer, A 2013, 'Small and medium $\square$ sized enterprises and sustainability: Managers' values and engagement with environmental and climate change issues', Business Strategy and the Environment, vol. 22, no. 3, pp. 173-186.

32. Yu, J \& Bell, JNB 2007, 'Building a sustainable business in China's small and medium-sized enterprises (SMEs)', Journal of Environmental Assessment Policy and Management, vol. 9, no. 1, pp. 19-43.

\section{About our Authors}

R. Nandagopal was the Director of PSG Institute of Management Director 2000 onwards. He has over three decades of academic experience serving in various capacities at leading institutions like Institute of Public Enterprise, Hyderabad and Loyola College, Madras. He is the founder member of ABBS and has held leadership positions in National and Regional organizations that include AIMA, AIMS, CII, ICC, CMA and Productivity Council. He is presently on the board of Commissioners at ACBSP. He has been awarded the Honorary Citizen of Toledo, Ohio, USA for his contribution to the Indo American Education Initiative. He received his Ph.D. in Finance in 1985 from the University of Madras and published 75 articles in national and International Journals and authored 17 books in Management.

B. Uma Maheswari having specialized in Strategic Management, Business Analytics and Entrepreneurship has been certified by the Wharton Business School, 
University of Pennsylvania for the completion of their online course on Business Analytics. She has undergone training through various programs organized by IIT, IIM and ISB including a Certificate Programme for Entrepreneurship conducted by the Whadwani Center for Entrepreneurship, ISB, Hyderabad. She has also published many research papers in various national and international journals. She is the coordinator of the entrepreneurship cell at PSG IM and has been instrumental in nurturing several start-up ideas of students. Her International exposure includes visiting numerous academic Institutions of excellence in the United States of America such as Harvard Business School, Carnegie Mellon University etc.

D. Kavitha an Assistant Professor has academic and research interests in accounting, finance, corporate governance, corporate social responsibility and higher education. Her doctoral research was on the Impact of Corporate Governance on the Disclosure Practices of listed firms. She has participated and presented papers in several national and international conferences in the domain of governance, higher education and accreditation. Her papers have been published in several national and international journals of repute. She has been trained at Harvard Business School in case teaching and innovation in teaching and course design. As a member of PSGIM's Accreditation team she played a significant role in the institution's efforts in its pursuit of international accreditations. 